\title{
Model Assessment of Potential Risk Associated with Common Fish Species from Oguta Lake, Nigeria
}

\author{
Verla Andrew Wirnkor ${ }^{1 *}$, Joel Ejike Ejiako ${ }^{1,}$ Verla Evelyn Ngozi $^{2}$, Iwuoha Godson Ndubuisi ${ }^{4}$ \\ ${ }^{1}$ Department of Chemistry, Faculty of Science, Imo State University Owerri, Imo State, Nigeria. \\ ${ }^{2}$ Department of Environmental Technology, Federal University of Technology Owerri, Imo State, Nigeria \\ *Corresponding Author: Verla Andrew Wirnkor, Department of Chemistry, Faculty of Science, Imo State \\ University Owerri, Imo State, Nigeria
}

\begin{abstract}
Fish can bioconcentrate heavy metals which become absorbed into the human body through the food chain. In this study, four fish species from Ogutalake were analysed for metal concentration and data subjected to some chemometric assessment. $1 \mathrm{~g}$ each of the 4 fish samples were weighed and digested in $5 \mathrm{~mL}$ of nitric acid. The digested samples were analysed for heavy metals using GBC scientific sensAA dual Atomic Absorption Spectrophotometer. Contamination factors were generally low $(C f<6)$. However, contamination factors were significant except for manganese, zinc and copper in all fish samples. The pollution load index are in the order Okpo>Ubu>Ifuru>Egu respectively. Okpo showed highest daily dietary intake amongst all fish species with about $0.826 \mathrm{mg} / \mathrm{kg} / \mathrm{Bw} /$ day in children, while adults EDI had $0.142 \mathrm{mg} / \mathrm{kgBWday}-1$. Other fishes showed much lower values of EDI in the following order: Egu<Ifuru<Ubu<Okpo. All fish exhibited values lower than the recommended daily intake $(12500 \mathrm{mg} / \mathrm{kg} /$ day) set by NRC. The mean EDI were in the following order: $\mathrm{Zn}>\mathrm{Mn}>\mathrm{Ni}>\mathrm{Cd}>\mathrm{Cu}$. Weak positive correlations were exhibited by Ni/Mn (0.26) and $\mathrm{Zn} / \mathrm{Cd}(0.14)$ while strong positive correlations were between $\mathrm{Cd} / \mathrm{Mn}(0.81)$ and $\mathrm{Zn} / \mathrm{Cu}(0.83)$. Significant negative correlations were exhibited between $\mathrm{Ni} / \mathrm{Zn}(-0.96), \mathrm{Ni} / \mathrm{Cu}(-0.79)$ and $\mathrm{Cu} / \mathrm{Mn}(-0.64)$ respectively. The positive and negative correlations suggest that the metals had similar and dissimilar sources of contamination. The study showed that, consumption of fish from Ogutalake could pose health hazards.
\end{abstract}

Keywords: Anthropogenic, Contamination, Pollution, Toxicity, Species, Health hazards.

\section{INTRODUCTION}

Fish is a good source of protein and it is consumed by most people in the world. Fishes have been recognised as good accumulators of organic and inorganic pollutants [1]. Oguta Lake has a history of oil spillage. Moreover, the lake is used for transportation and there is constant dredging activities going on the lake which could contribute to the concentration of these pollutants through emission from the exhaust and possible leakages of the oil from the tanks of the machines. Again, the lake serves as a source of water and fish for Oguta people and also an outlet for sewage.

Studies have shown that the various anthropogenic activities at the lake are detrimental to the water quality as well as fishes in the water. A researcher [2] assessed some important physical and environmental aspects of Oguta Lake and its watershed, Niger Delta Basin. The result from the study showed that the areas covered by the Oguta Lake water body is about $1,870.4 \mathrm{~m}^{2}(68.2 \%)$ while degraded portions of the lake occupied an area of $1152.25 \mathrm{M}^{2}(38.8 \%)$. The degraded portion according to the work was with a total area of $1099.97 \mathrm{~m}^{2}(36.91 \%)$, areas covered by sediments and eutrophication with total areas of $41.3 \mathrm{~m}^{2}(1.39 \%)$ and $14.9 \mathrm{~m}^{2}(0.5 \%)$, respectively which was attributed to anthropogenic activities in the lake. The study also showed that built-up areas outside the vicinity of the lake with an area of about $4,983.3 \mathrm{~m}^{2}$ have very strong positive correlation $\left(\mathrm{R}^{2}=1\right)$ with the degradable portions of the lake. This means that the lake is polluted and anthropogenic activities are mainly responsible for the degradation of the lake.Research[3] assessed the quality of water and heavy metal content of fish species from OgutaLake in Imo state. Chromium, iron, nickel, cadmium and copper were dictated and lead, mercury and arsenic were absent.The concentrations of the metals were higher in Mudfish and Tilapia while the lower concentrations alternated between Catfish and Ifuru. Cadmium, nickel and iron levels exceeded permitted limit of Nigerian Industrial Standard (NIS) in all the samples except for copper. It was concluded that the water of Oguta Lake will sustain aquatic life 
because of the high level of dissolved oxygen and low level of BOD. However, the raw domestic use of the water without treatment is reported to be dangerous as the levels of Turbidity, Nitrate, Total Coliform, Iron, Cadmium and Nickel exceeded the maximum permissible limit of Nigerian Industrial Standard.

The inhabitants of Oguta local government and the surrounding communities depend on Oguta Lake for their source of fish and water for domestic uses and fishes are known for their ability to bioconcentrate toxic substances in their muscles and fats. The consumption of fishes that are contaminated with heavy metals is detrimental to human health. These facts therefore, and the risks of consuming fish and fish products that are contaminated with heavy metal propelled the necessity of this research work to ascertain the quality of fishes from Oguta Lake. To achieve the aim of the study the following specific objectives were set;to determine the contamination level and pollution status of heavy metals in the fish samples from the lake, to estimate the daily exposure of heavy metals in the fish species from Oguta lake, to determine the significant relationship between the concentration of the heavy metals among the fish species from the lake

The extent of this research work covered the assessment of heavy metal such as Zinc (Zn), Copper ( $\mathrm{Cu})$ ,Nickel (Ni), Cadmium(Cd), and Manganese (Mn) in fish species from Oguta Lake. This research will help to ascertain the toxic level of fishes from Oguta Lake and afterwards, will provide useful information on the quality of fish from the Lake.Plates a and b show some anthropogenic activities taking place in and around Oguta lake.

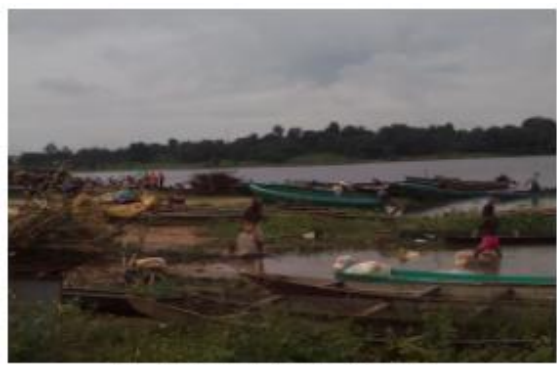

(a) Transportation across lake

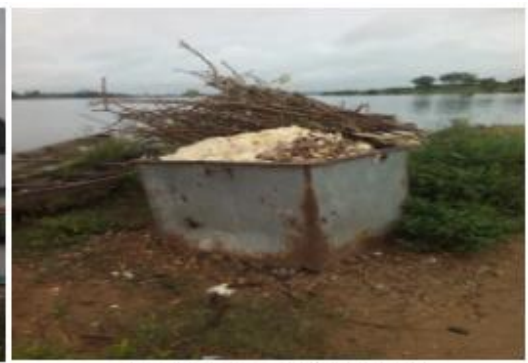

(b) waste dumped at lake site

\section{MATERIALS AND MeTHODS}

\subsection{Location of Study}

Oguta Lake is the largest natural Lake in south eastern Nigeria. It is natively called 'OHAMIRI' which is interpreted as the goddess of the lake [4]. The Lake is about 30 miles(48.27 km) from Ndoni and Urashi junction, 5 miles $(8.05 \mathrm{~km})$ long from east to west and one and half miles wide [5]. It lies approximately within Latitude $5^{0} 41$ and $5^{\circ} 44$ North and Longitude $6^{0} 50$ and $6^{0} 45$ east It receives inflow from Njaba river, Awbamariver, Orashi river and Utu river. The lake has maximum surface area of 2.48 $\mathrm{km}^{2}$ with maximum depth of about8m [6]. The lake serves as a source of transportation, tourism, and water for domestic uses, fish and also an outlet for sewage [6]. Ongoing activities in the lake include; transportation by means of paddle and dugout canoe or the use of engine-powered boat, peeling, washing and fermentation of cassava. Other activities are washing of clothes, cars, motorcycles, kitchen utensils, bathing and fishing.

\subsection{Samples Collection}

Four fish samples that are mostly consumed by the inhabitants of the study area were bought from fisher men at the bank of the lake, put in a polyethene bags and transported to Imo State University laboratory. The fishes collected were; mochokidae, perpyroclanusalpha, cintharinidae and ciclidae, they are locally known as Okpo, Ubu, Ifuru and Egu respectively. Each fish species was properly washed with distilled water to remove debris, plankton and external adherent and were drained under folds of filter, weighed and wrapped in aluminium foil. All the four samples were then separately stored inside deep freezer and allowed to thaw. The scales were removed and washed with clean water.

\subsection{Sample Preparation}

Prior to extraction, the four fish samples were dried in the laboratory oven until a constant dry weight was obtained from each sample. The dried samples were ground to powder using ceramic mortar and pestle. Ground samples were then sieved with $2 \mathrm{~mm}$ sieve. 


\subsection{Samples Digestion}

$1 \mathrm{~g}$ each of the fish samples were weighed and digested in $5 \mathrm{~mL}$ of nitric acid. The mixtures were allowed to stand for nine hours. Each sample was digested twice then the digested samples were transferred into volumetric flask and made up to the mark using distilled water. The digested samples were analysed for heavy metals using GBC scientific sensAA dual Atomic Absorption Spectrophotometer.

\subsection{Data Analysis}

The data obtained were interpreted using some statistical analysis such as mean, standard deviation and correlation analysis and chemometricassessment using assessment models such as contamination factors, pollution load index, estimated dietary intake and target hazard quotient.

\subsubsection{Statistical Analysis}

The data were analysed using mean, standard deviation and Spearman's correlation coefficient. Graphs and charts were also used to compare data obtained from the different fish samples. Spearman's correlation coefficient was employed for the purpose of establishing relationships between heavy metals found in the four fish samples.

\subsubsection{Chemometric Assessment}

The data obtained were subjected to chemometric analysis using some assessment models such as contamination factors, pollution load index, estimated dietary intake and target hazard quotient.

\subsubsection{Contamination Factor and Pollution Load Index}

The results obtained for heavy metals were interpreted with contamination and pollution index models. The contamination factor and pollution load index were determined mathematically as expressed in equation (1) and (2) respectively. This was done to determine the contamination level and pollution status of heavy metals in the fish samples.

$\mathrm{CF}=\frac{\mathrm{C}_{\mathrm{m}}}{\mathrm{C}_{\mathrm{b}}} \ldots \ldots \ldots \ldots \ldots \ldots$

Where $\mathrm{Cm}$ is the concentration of the metal in the fish and $\mathrm{Cb}$ is the reference concentration of the metal. FAO standards for heavy metals in fish were taking as the reference concentration. The values were Ni- $0.06 \mathrm{mg} / \mathrm{kg}$, Cd- $0.05 \mathrm{mg} / \mathrm{kg}, \mathrm{Zn}-40 \mathrm{mg} / \mathrm{kg}$, and Cu-10 mg/kg. Manganese was as $20 \mathrm{mg} / \mathrm{kg}$ taken from the proposed permissible limit of manganese concentrations in fish species as recorded by Turkish guidelines known as Turkish Food Codes (TFC) [7], [8], [9], [10].

$$
\mathrm{PLI}=\left(\mathrm{CF}_{1} \mathrm{XCF}_{2} \mathrm{XCF}_{3} \ldots \ldots \mathrm{CF}_{\mathrm{n}}\right)^{1 / \mathrm{n}} \ldots \ldots \ldots \ldots \ldots \ldots \ldots
$$

Where $\mathrm{n}$ is the number of metals considered in the study and $\mathrm{CF}_{\mathrm{i}}$ is the contamination factor for each individual metal.

\subsubsection{Estimated Dietary Intake (EDI)}

The EDI of metals (polar and nonpolar) in fish from consumption was evaluated using the mathematical expression

EDI $(\mathrm{ug} / \mathrm{kgbw}) /$ day $)=\frac{\text { MixCM }}{\mathrm{BWA}} \ldots \ldots \ldots \ldots \ldots \ldots \ldots$

$\mathrm{MI}=$ mass of fish ingested per day, $\mathrm{CM}=$ concentration of metal in fish, $\mathrm{BWA}=$ body weight for average adult is $70 \mathrm{~kg}$. The mass of the fish ingested per day in Nigeria is $7.6 \mathrm{~kg}$ which is equivalent to $20.8 \mathrm{~g}$ per day. In the case of children the mass of BWC was taken as $12 \mathrm{Kg}$ (Ref). RFD = oral reference dose. This is an estimate of daily exposure to human population that is likely to be without an appreciable risk of deleterious effect during life time.

\subsubsection{Target Hazard Quotient (THQ)}

The THQ of metals in fish from consumption was evaluated using the mathematical expression

THQ $=\frac{\text { EFxEDxEDI }}{\text { RFDXAT }} \times 10^{-3}$

$\mathrm{EF}=$ exposure frequency 365 days, $\mathrm{ED}=$ exposure duration which corresponds to average life expectancy in Nigeria (54.5 years), AT = averaging exposure time for non-carcinogens (19892.5 days), 
RFD = Oral Reference Dose. Some oral reference dose include Cd $0.001 \mathrm{mg} / \mathrm{kg}$-day, $\mathrm{Cu} 0.04 \mathrm{mg} / \mathrm{kg}$ day, Zn 0.3 mg/kg-day, Ni 0.02 mg/kg-day, Mn 0.14 mg/kg-day [11].

\section{RESULTS AND DISCUSSION}

The concentrations and statistical summary of nickel, manganese, zinc, copper and cadmium in the fish species are shown in (table 1). Heavy metal were present in all fish species in Oguta Lake. This may be due to the ability of fish to bioaccumulate these metals into their body tissues from the aquatic environment. The bioaccumulation of metals by fish has been reported by many researchers including [12]. Metals including $\mathrm{Ni}, \mathrm{Mn}, \mathrm{Zn}, \mathrm{Cu}$ and $\mathrm{Cd}$ were bioaccumulated to varying levels. This is because fish like other aquatic organisms, have the ability to concentrate heavy metals in their tissues to concentration levels which comprised of several orders of magnitude higher [13].

\subsection{Nickel (Ni)}

There is evidence of uptake and accumulation of nickel in fishes. Nickel is an essential trace element in animals, although the functional importance of nickel has not been clearly demonstrated. It is considered essential based on reports of nickel deficiency in several animal species. Nickel deficiency is manifested primarily in the liver; effects include abnormal cellular morphology, oxidative metabolism, and increases and decreases in lipid levels. Decreases in growth and haemoglobin concentration and impaired glucose metabolism have also been observed. The essentiality of nickel in humans has not been established, and nickel dietary recommendations have not been established for humans [14]. Nickel compounds are known carcinogens in both human and animal models [15], [16]. There is evidence that the genotoxic effects of nickel compounds may be indirect through the inhibition of DNA repair systems. As a result of this inhibition it has been suggested that accumulation of nickel in breast tissue may be closely related to malignant growth process [17], [18], [19].

The concentration of nickel ranged from $0.094 \mathrm{mg} / \mathrm{kg}$ in Ubuto $0.221 \mathrm{mg} / \mathrm{kg}$ in Ifuruwith mean of $0.158 \mathrm{mg} / \mathrm{kg}$ (table 2). The mean value of $\mathrm{Ni}$ in the fish samples were in the order $\mathrm{Ubu}<\mathrm{Egu}<\mathrm{Okpo}<\mathrm{Ifuru}$. The concentrations of $\mathrm{Ni}$ were generally higher than FAO standard of 0.06 $\mathrm{mg} / \mathrm{kg}$. This implies that fish from Oguta Lake shows possible contamination and could be considered unsafe for human consumption. High level of Ni from this study may be as a result of domestic wastewater from numerous activities near the lake as well as mechanized activities conducted on the river and this could provide possible explanation for this finding.

\subsection{Manganese (Mn)}

Manganese is essential for normal development and body function across the life span of all mammals [20]. Manganese binds to and/or regulates many enzymes throughout the body. It is a required co-factor for arginase, which is responsible for urea production in the liver, superoxide dismutase, which is critical to prevent against cellular oxidative stress, and pyruvatecarboxylase, an essential enzyme in gluconeogenesis. The brain is the major target organ for manganese toxicity as it retains manganese much longer than other tissues. Following chronic overexposure, manganese can produce a progressive, permanent neurodegenerative disorder, with few options for treatment and no cure [20], [21], [22].

Fish species can have up to $5 \mathrm{mg} / \mathrm{kg}$ and mammals up to $3 \mathrm{mg} / \mathrm{kg}$ in their soft tissues, although typically they have around $1 \mathrm{mg} / \mathrm{kg}$ due to its vital role in human health, however, excesses or lacks of manganese concentrations level can cause health effects [23]. The concentrations of Mn were ranged from 0.024 to $0.474 \mathrm{mg} / \mathrm{kg}$ with a mean concentration of $0.175 \mathrm{mg} / \mathrm{kg}$. The proposed permissible limit of manganese concentrations in fish species as recorded by Turkish guidelines known as Turkish Food Codes (TFC) is about $20 \mathrm{mg} / \mathrm{kg}$ [24]. In general it can be seen that the concentrations of Mn found in edible part of the fishes in the present study are still considered as those of uncontaminated fish $(<20)$. However, Mn was recorded highest in Okpo and Egu recorded lowest.

Table1. Statistical summary of metal concentration in the various fish species

\begin{tabular}{|c|c|c|c|c|c|c|}
\hline Parameter & Okpo & Ubu & Ifuru & Egu & $\mathbf{M} \quad \mathbf{e} \quad \mathbf{a} \quad \mathbf{n}$ & FA0 $0(1983)$ \\
\hline $\mathrm{Ni}(\mathrm{m}$ & $0.162 \pm 0.04^{*}$ & $0.094 \pm 0.02^{*}$ & $0.221 \pm 0.02^{*}$ & $0.154 \pm 0.03^{*}$ & $\begin{array}{lllll}0 & . & 1 & 5 & 8\end{array}$ & $\begin{array}{llll}0 & . & 0 & 6\end{array}$ \\
\hline $\mathrm{Mn}(\mathrm{mg} / \mathrm{kg})$ & $0.474 \pm 0.17$ & $0.050 \pm 0.02$ & $0.151 \pm 0.05$ & $0.024 \pm 0.03$ & 0.175 & $\mathrm{~N}$ \\
\hline $\mathrm{Zn}(\mathrm{mg} / \mathrm{kg})$ & $0.585 \pm 0.06$ & $0.852 \pm 0.12$ & $0.401 \pm 0.04$ & $0.527 \pm 0.18$ & $\begin{array}{lllll}0 & . & 5 & 9 & 1\end{array}$ & 4 \\
\hline
\end{tabular}




\begin{tabular}{|l|l|l|l|l|llll|lll|}
\hline $\mathrm{Cu}(\mathrm{mg} / \mathrm{kg})$ & $0.009 \pm 0.00$ & $0.026 \pm 0.02$ & $0.012 \pm 0.01$ & $0.014 \pm 0.01$ & 0.0 & 1 & 5 & 1 & 0 \\
\hline $\mathrm{Cd}(\mathrm{mg} / \mathrm{kg})$ & $0.075 \pm 0.08^{*}$ & $0.026 \pm 0.01$ & $0.010 \pm 0.01$ & $0.033 \pm 0.01$ & 0 & 0 & 3 & 6 & 0 & 0 & 5 \\
\hline
\end{tabular}

*= indicates concentration higher than the permissible limit set by FAO (1983).

\subsection{Zinc (Zn)}

Zinc is an essential nutrient in humans and animals and is necessary for the function of a large number of metalloenzymes. These enzymes include alcohol dehydrogenase, alkaline phosphatase, carbonic anhydrase, leucineaminopeptidase, superoxide dismutase, and deoxyribonucleic acid (DNA) and ribonucleic acid (RNA) polymerase. An acute oral dose of zinc may cause symptoms such as tachycardia, vascular shock, dyspeptic nausea, vomiting, diarrhoea, pancreatitis and damage of hepatic parenchyma [25], [26].

When high levels of zinc are ingested inhibition of copper absorption through interaction with metallothionein at the brush border of the intestinal lumen occurs. Both copper and zinc appear to bind to the same metallothionein protein; however, copper has a higher affinity for metallothionein than zinc and displaces zinc from metallothionein protein. Copper complexed with metallothionein is retained in the mucosal cell, relatively unavailable for transfer to plasma, and is excreted in the faeces when the mucosal cells are sloughed off. Thus, an excess of zinc can result in a decreased availability of dietary copper, and the development of copper deficiency [27], [28].

On the other hand zinc deficiency has been associated with dermatitis, anorexia, growth retardation, poor wound healing, hypogonadism with impaired reproductive capacity, impaired immune function, and depressed mental function; increased incidence of congenital malformations in infants has also been associated with zinc deficiency in the mothers [29]. This can be observed in the table 3.0 where higher values were obtained for zinc and lower values for copper.

Zinc concentrations in general were below the limit of $40 \mathrm{mg} / \mathrm{kg}$ set by [30] with mean of $0.591 \mathrm{mg} / \mathrm{kg}$ and were in the order of Ifuru $<\mathrm{Egu}<\mathrm{Okpo}<\mathrm{Ubu}$ respectively. The zinc concentrations could be considered safe for consumption in these fishes.

\subsection{Copper $(\mathrm{Cu})$}

Copper is an essential nutrient that is incorporated into a number of metalloenzymes involved in haemoglobin formation, drug/xenobiotic metabolism, carbohydrate metabolism, catecholamine biosynthesis, the crosslinking of collagen, elastin, and hair keratin, and the antioxidant defense mechanism. Copper-dependent enzymes, such as cytochrome $\mathrm{C}$ oxidase, superoxide dismutase, ferroxidases, monoamine oxidase, and dopamine $\beta$ - monooxygenase, function to reduce activated oxygen species or molecular oxygen. Symptoms associated with copper deficiency in humans include normocytic, hypochromic anaemia, leukopenia, and osteoporosis [31].

Although copper homeostasis plays an important role in the prevention of copper toxicity, exposure to excessive levels of copper can result in a number of adverse health effects including liver and kidney damage, anaemia, immunotoxicity, and developmental toxicity. Many of these effects are consistent with oxidative damage to membranes or macromolecules. Copper can bind to the sulfhydryl groups of several enzymes, such as glucose-6-phosphatase and glutathione reductase, thus interfering with their protection of cells from free radical damage [32].

The mean concentration of $\mathrm{Cu}$ in fish caught in Oguta Lake was low. The low copper level could be due to the high zinc concentrations in the fishes, as excess of zinc can result in a decreased availability of dietary copper, and the development of copper deficiency [27], [28]. However, the mean value of Cu $(0.033 \mathrm{mg} / \mathrm{kg})$ in ciclidae was higher than values recorded in Okpo, Ubu and Ifuru. The values recorded in the different fishes from at the Lake were lower than the standard limit of $10 \mathrm{mg} / \mathrm{kg}$ recommended by FAO for fish and fishery products. This implies that fishes from Oguta Lake could be considered safe for consumption for copper.

\subsection{Cadmium (Cd)}

Cadmium (Cd) is one of the most toxic elements to which man can be exposed at work or in the environment. Once absorbed, $\mathrm{Cd}$ is efficiently retained in the human body, in which it accumulates throughout life [33]. Bioaccumulation of cadmium takes place at tropic level and found to be highest in 
algae [34]. It also accumulates in considerable concentrations in various organs of fish [35], [36]. Ref. [12] reported that cadmium accumulates in tissues of carp Cyprinuscarpio in following order: kidney> Liver> Gills. Ref. [37] also reported similar accumulation pattern in Clariasbatrachus in an experimental study. Kidney is the prime target organ for cadmium. The liver also stores a considerable part of the accumulated cadmium. Cadmium is redistributed to these organs directly following uptake through the gills and intestine, but there may also be redistribution of cadmium from other organs [38]. High levels of $\mathrm{Cd}$ in fish are potential risk concern on human consumer's health such as kidney damage (renal tubular damage).

The found cadmium concentrations were ranged from 0.010 to $0.075 \mathrm{mg} / \mathrm{kg}$ with a mean concentration of $0.036 \mathrm{mg} / \mathrm{kg}$. This finding is in agreement with previous observations recorded by Suresh et al., (2007) for commercially valuable marine eatable fishes from Parangipettai coast, south east coast of India (0.18-0.54 mg/kg dry wt.). Ref. [39] documented higher concentrations of Cd as compared with this study where $\mathrm{Cd}$ mean concentrations were ranged between 0.37 and $0.79 \mathrm{mg} / \mathrm{kg}$ in the fish species of Mediterranean Sea. Ref. [40] reported higher concentrations of Cd as compared to the present study with mean concentration of $0.058 \mathrm{mg} / \mathrm{kg}$ for fish muscles collected from Kapar and Mersing coastal waters in Malaysia. Additionally, the Cd concentrations in the muscles of different marine fishes harvested from Masan Bay, Korea $(0.02 \mu \mathrm{g} / \mathrm{g}$ to $0.05 \mu \mathrm{g} / \mathrm{g}$, dry weight) [41] were lower than those reported in this present study. The proposed limits of Cd set by [42] for eatable fish is about $0.05 \mathrm{mg} / \mathrm{kg}$. All fish samples are lower than this limit except for Okpo $(0.075 \pm 0.08 \mathrm{mg} / \mathrm{kg})$. Thus, cadmium appears to present a contaminant hazard to Okpo within this range of concentrations.

The degree of contamination was calculated to determine the extent and pollution status of the studied metals in the fish samples. The following terminologies were used to describe the degree of contamination; $\mathrm{Cf}<6$, low degree of contamination; $6 \leq \mathrm{Cf}<12$, moderate degree of contamination; $12 \leq \mathrm{Cf}<24$, considerable degree of contamination; $\mathrm{Cf} \geq 24$, very high degree of contamination. In the present study, all studied heavy metals generally were low since $\mathrm{Cf}<6$. However, contamination factors were significant except for manganese, zinc and copper in all fish samples (figure 2). The pollution load index is a potent tool in heavy metal pollution evaluation that provides a simple and comparative means for assessing the level of heavy metal pollution. The PLI represents the number of times by which the metal content in the fish exceeds the standard concentration, and gives a summative indication of the overall level of heavy metal toxicity in a particular sample. The PLI value of $>1$ is polluted, $<1$ indicates no pollution whereas values of PLI $=1$ indicate heavy metal loads close to the standard. Therefore, the five studied fish isn't polluted for the metals studied. However, the PLI are in the order; Okpo $>$ Ubu $>$ Ifuru $>$ Egurespectively.

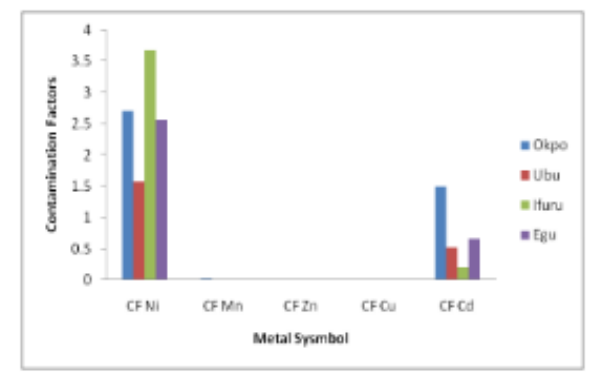

Figure2. $C F$ for the studied metals in the different fish

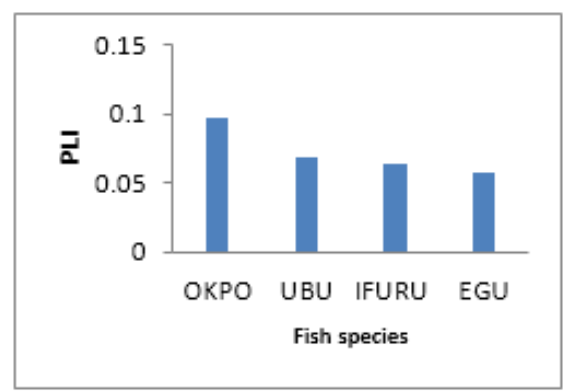

Figure3. PLI of metals in fish samples from Ogutalake

Table 2.shows the provisional tolerable daily intake in adult and children who consumed fish species from Oguta Lake. Okposhowed highest daily dietary intake amongst all fish species withup to 0.826 
$\mathrm{mg} / \mathrm{kg} / \mathrm{Bw} / \mathrm{day}$ in children, while adults EDI had $0.142 \mathrm{mg} / \mathrm{kgBWday}^{-1}$. Other fishes showed much lower values of EDI in the following order: Egu $<$ Ifuru $<\mathrm{Ubu}<\mathrm{Okpo}$. All fish exhibited values lower than the recommended daily intake $(12500 \mathrm{mg} / \mathrm{kg} / \mathrm{day})$ set by [43]. The mean EDI for the various metals in the fish species from Oguta Lake were in the following order: $\mathrm{Zn}>\mathrm{Mn}>\mathrm{Ni}>\mathrm{Cd}>\mathrm{Cu}$.

Table2. Estimated Dietary intake and Target Hazard Quotient of metals from fish species

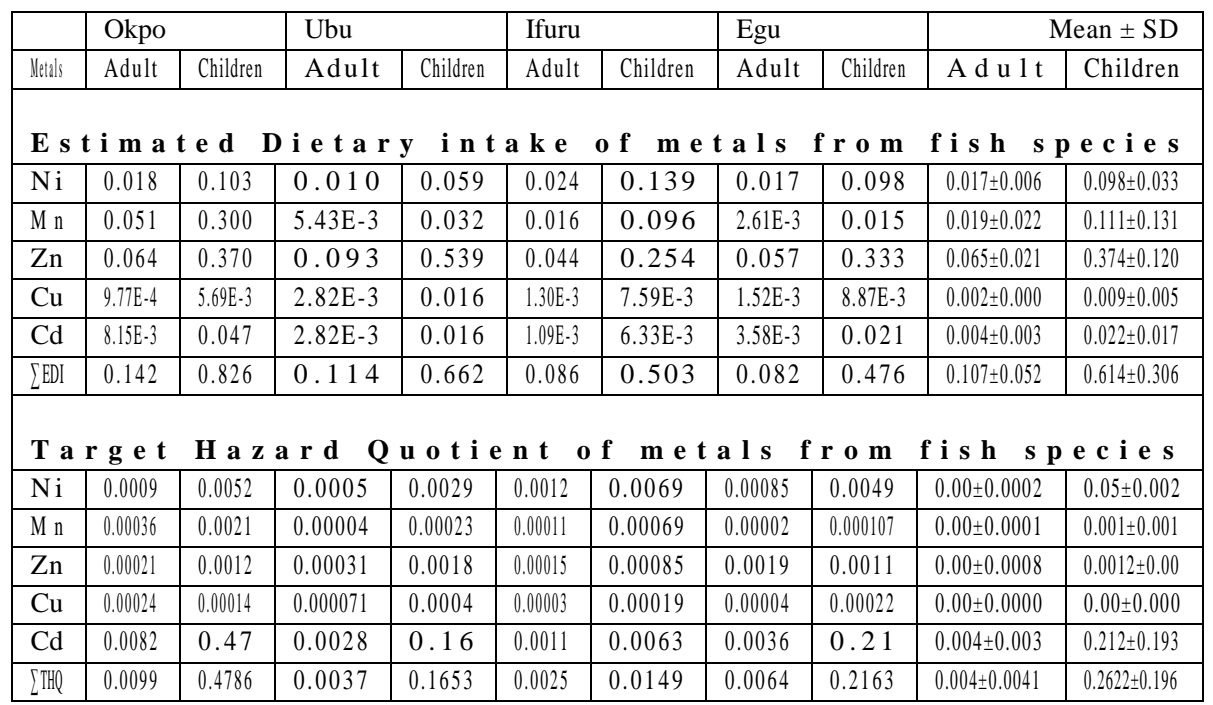

For adult, nickel showed EDI values ranging from $0.010 \mathrm{Mg} / \mathrm{Kg} / \mathrm{Bw} /$ day (Ubu) to $0.024 \mathrm{Mg} / \mathrm{Kg} / \mathrm{Bw} /$ day for Ifuru, Manganese showed values ranging from $2.61 \mathrm{E}-3 \mathrm{Mg} / \mathrm{Kg} / \mathrm{Bw} / \mathrm{day}$ in Ubu to 0.051 $\mathrm{Mg} / \mathrm{Kg} / \mathrm{Bw} /$ day in Okpo, Zinc showed mean EDI values ranging from Ifuru (0.044) to Ubu (0.093). Copper had mean EDI values of Ifuru (1.30E-3) to Okpo(9.77E-4). While Cadmium showed mean EDI ranging from 1.09E-3 Mg/KgBw/day for Ifuru to $8.15 \mathrm{E}-3 \mathrm{Mg} / \mathrm{KgBw} /$ day for Okpo. However, for children, nickel showed EDI values ranging from $0.059 \mathrm{Mg} / \mathrm{Kg} / \mathrm{Bw} / \mathrm{day}$ (Ubu) to $0.139 \mathrm{Mg} / \mathrm{Kg} / \mathrm{Bw} / \mathrm{day}$ for Ifuru, Manganese showed values ranging from $0.015 \mathrm{Mg} / \mathrm{Kg} / \mathrm{Bw} /$ day in Egu to $0.3 \mathrm{Mg} / \mathrm{Kg} / \mathrm{Bw} / \mathrm{day}$ in Okpo, Zinc showed EDI values ranging fromIfuru (0.254) to Ubu (0.539). Copper had mean EDI values of Ifuru (0.016) to Egu (5.69E-3). While Cadmium showed mean EDI ranging from 6.33E-3 $\mathrm{Mg} / \mathrm{KgBw} /$ day for Ifuru to $0.047 \mathrm{Mg} / \mathrm{KgBw} /$ day for Okpo.

EDI for fish species from Oguta Lake showed that amongst the heavy metals that may be toxic to living systems $\mathrm{Zn}$ had highest value in the case of children and adults followed by manganese, then nickel, cadmium and copper. These EDI: $\mathrm{Zn}<\mathrm{Mn}<\mathrm{Ni}<\mathrm{Cd}<\mathrm{Cu}$ values though low, could constitute a source of danger for consumers of fish.

THQ is the hazard quotients for substances that affect the same target organ or organ system. Also, it is the ratio of the potential exposure to the substance and the level at which no adverse effects are expected. A hazard quotient less than or equal to one indicates that adverse noncancer effects are not likely to occur, and thus can be considered to have negligible hazard. HQs greater than one is not a statistical probability of harm occurring. Instead, they are a simple statement of whether (and by how much) an exposure concentration exceeds the reference concentration (RfC) [45]. However, in the present study the THQ were generally less than one. This implies that the fishes from Oguta Lake can be considered safe for consumption and adverse noncancer effects are not likely to occur.

Figures 3-6 is show the THQ for various metals in the different fish samples from the lake.

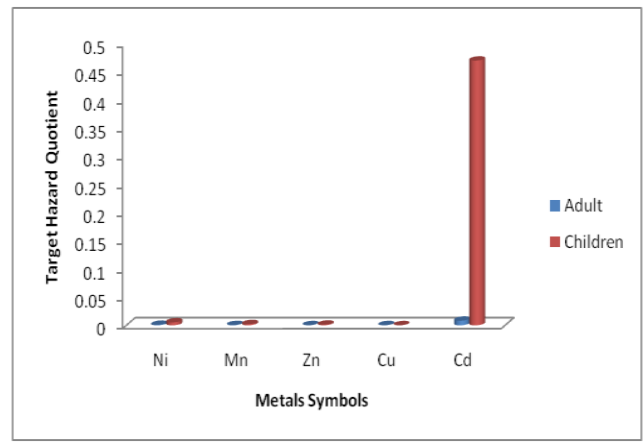

Figure4. Target Hazard Quotient in Okpo for adults and children 


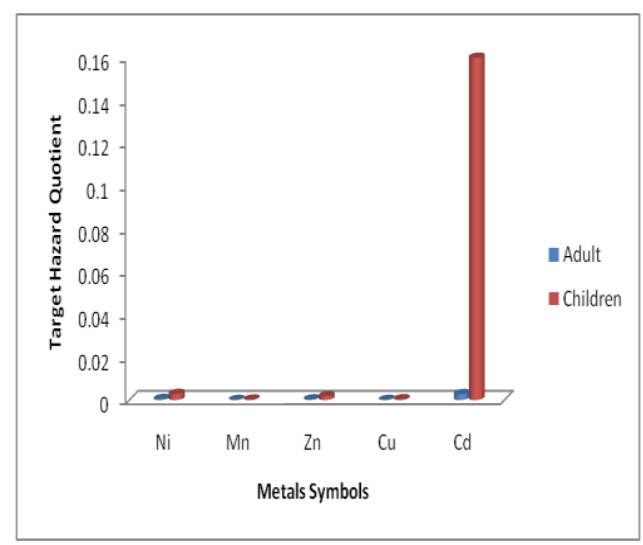

Figure5. Target Hazard Quotient inUbufor adults and children

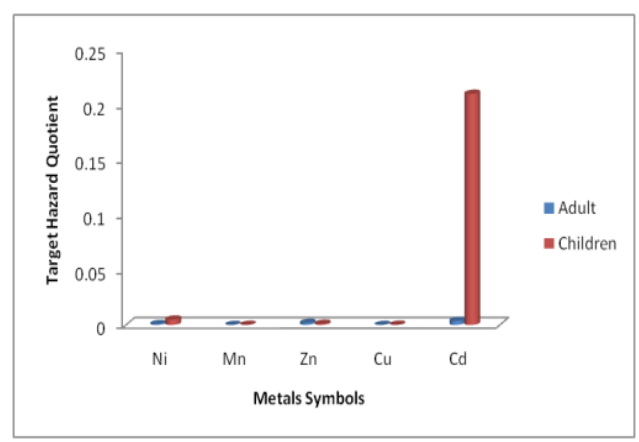

Figure6. $T H Q$ in Ifuru for adults and children

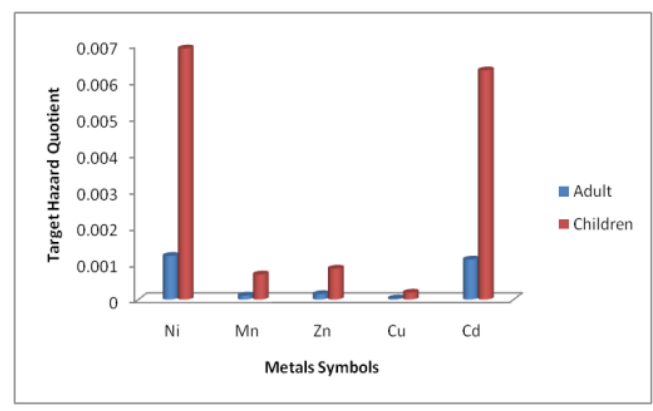

Figure7. THQ in Egu for adults and children

Table3. Correlation matrix of metals in the various fish species

\begin{tabular}{|c|c|c|c|c|c|}
\hline & $\mathrm{Ni}$ & $\mathrm{Mn}$ & $\mathrm{Zn}$ & $\mathrm{Cu}$ & $\mathrm{Cd}$ \\
\hline $\mathrm{Ni}$ & 1 & & & & \\
\hline $\mathrm{Mn}$ & 0.257 & 1 & & & \\
\hline $\mathrm{Zn}$ & -0.960 & -0.171 & 1 & & \\
\hline $\mathrm{Cu}$ & 0.786 & -0.637 & 0.833 & 1 & \\
\hline $\mathrm{Cd}$ & -0.192 & 0.813 & 0.1448 & -0.424 & 1 \\
\hline
\end{tabular}

The correlation matrix was used to establish relationship between data of metal concentrations in fish and also helps to establish similar or dissimilar source of contamination. The matrix is ranked from +1 (positive correlation), 0 (no correlation), and -1 (negative correlation). The correlation matrix of metals is presented in table 5 . Weak positive correlations were exhibited by Ni/Mn $(0.26)$ and $\mathrm{Zn} / \mathrm{Cd}(0.14)$ while strong positive correlations were between $\mathrm{Cd} / \mathrm{Mn}(0.81)$ and $\mathrm{Zn} / \mathrm{Cu}(0.83)$. Significant negative correlations were exhibited between $\mathrm{Ni} / \mathrm{Zn}(-0.96), \mathrm{Ni} / \mathrm{Cu}(-0.79)$ and $\mathrm{Cu} / \mathrm{Mn}(-0.64)$ respectively. The positive and negative correlations suggest that the metals had similar and dissimilar sources of contamination. Therefore, $\mathrm{Cd} / \mathrm{Mn}, \mathrm{Zn} / \mathrm{Cu}$ has similar sources of contamination while $* \mathrm{Ni} / \mathrm{Zn}, \mathrm{Ni} / \mathrm{Cu}$ and CU/Mn had different sources of contamination

\section{Conclusion}

All the fish species studied had higher THQ in children than in adults; so, children are at a higher risk of harm than adults. Though the pollution levels of the heavy metals were generally low, the study 
showed that the fish samples from Oguta Lake were contaminated with Nickel and Manganese, therefore the amount of fishes from Oguta lake that is consumed should be checked as they could constitute health hazards arising from heavy metals contamination. Heavy metals contamination levels of fish from Oguta lake should be regularly monitored because there is the possibility of a high pollution of the metals in the fish from Ogutalake emanating from bioaccumulation of heavy metals

\section{REFERENCES}

[1] King R.P., Jonathan G.E., 2003. Aquatic environmental perturbation and monitoringAfrica experience.AmericanInternational Journal of Contemporary Research pp. 58,663-678.

[2] Ahiarakwem C.A., Nwankwor G.I., Onyekuru S.O., 2012. An assessment of the physical and environmental aspects of a tropical lake: A case study of the Oguta Lake watershed, Niger Delta basin, Nigeria. American International Journal of Contemporary Research Vol. 2 No. 7.

[3] Umunnakwe J.E., Aharanwa B., 2014. Assessment of water quality and heavy metal levels of fish species inOguta Lake, Imo State, Nigeria. Journal of Natural Sciences Research ISSN 2224-3186 (Paper) ISSN 2225-0921.

[4] Chuku and Gloria, 2005. Igbo Women and economic transformation in south eastern Nigeria 1900-1960 Rantledge. P.26 ISBNO-415-97210-8.

[5] OkonkwoUcheUwaezuoke, 2011. The aro host communities and continuity in intergroup suspicion in the oguta area. since pre-colonial times. Afro-Asian Journal of Social Sciences 2(2.4):1.

[6] Okoro B.U., Uzochukwu R.A., Chimezie N.M., 2014. River Basin of Imo State for sustainable water resources management J. Civil Environ. Engeneering pp 34-56.

[7] Dural M., Göksu M.Z.Y., and Özak A.A., 2007. Investigation of heavy metal levels in economically important fish species captured from the Tuzla lagoon. Food Chemistry, 102 (1): 415-421.

[8] Türkmen M., Türkmen A., Tepe Y., Töre Y., Ateş A., 2009. Determination of metals in fish species from Aegean and Mediterranean seas. Food Chemistry, 113 (1): 233-237.

[9] Yilmaz, F., 2009. The comparison of heavy metal concentrations (cd, cu, Mn, Pb, and $\mathrm{Zn}$ ) in tissues of three economically important fish (Anguilla anguilla, Mugilcephalusand Oreochromisniloticus) inhabiting Köycegiz Lake-Mulga (Turkey). Turkish Journal of Sciences \& Technology, 4(1): 7-15.

[10] TFC. 2002. Turkish Food Codes, Official Gazette, 23 September, No:24885.

[11] FAO (Food and Agriculture Organization), "Compilation of Legal Limits for Hazardous Substances in Fish and Fishery Products," FAO Fisheries Circular No. 464, 1983, pp. 5-100.

[12] Smet, M., and Blust, P., 2001. Chronic Accumulation of Cadmium in the edible Tissues of Oreochromisaurus(Steindachner): Modification by Mercury and Lead. Arch. Environ. Contam. Toxicol.,29, 8-14.

[13] United Nations Environmental Programme (UNEP). 2011. Environmental assessment of ogoniland. publishedby united nations environmental programme, Nairobi, Kenya. Pp 7-49, 198- 225. ISBN: 978-92807-3130-9.

[14] ATSDR 2003b. Draft toxicological profile for nickel. Atlanta, Georgia, United States. US Department of Health and Human Services. Agency for Toxic Substances and Disease Registry.

[15] Harman, D. 1981. The aging process. Proceedings of the National Academy of Sciences .USA, 78 (11), 7124-7128.

[16] Feder, J.N., Gnirke A., Thomas W., Tsuchihashi Z., Ruddy D.A., Basava A. \& Al, E. 1996. A novel MHC class I-like gene is mutated in patients with hereditary haemochromatosis. NatureGenetics, 13(4), 399-408.

[17] Rothenberg S.J., Karchmer S., Schnaas L., Perroni E., Zea F. \& Fernandez A.J., 1994. Changes in serial blood lead levels during pregnancy. Environmental Health Perspective, 102, 876-880.

[18] Beyersmann D. 2002. Effects of carcinogenic metals on gene expression. Toxicological Letters, 127, 63-68.

[19] ATSDR 2005a. Toxicological Profile for Nickel. Atlanta, Georgia, United States. US Department of Health and Human Services. Agency for Toxic Substances and Disease Registry.

[20] Keen C.L., Ensunsa J.L. \& Clegg M.S. 2000. Manganese metabolism in animals and humans including the toxicity of manganese, New York,Marcel Dekker.

[21] Carl G.F., Gallagher B.B. 1994. Manganese and epilepsy. Boca Rato, CRC Press.

[22] Crossgrove J., Zheng W. 2004. Manganese toxicity upon overexposure. NMR IN BIOMEDICINE, 17(8), 544-553.

[23] Barak N., Mason C. (1990). A survey of heavy metal levels in eels (anguillaanguilla) from some rivers in east anglia, england - the use of eels as pollution indicators, Internationale Revue DerGesamtenHydrobiologie, Vol. 75, No. 6, pp. 827-833 
[24] Ashraf W. (2005). Accumulation of heavy metals in kidney and heart tissues of Epinephelumicrodonfish from the Arabian Gulf. Environ Monit Assess. 101, 311..

[25] Salgueiro M.J., Zubillaga M., Lysionek A., Sarabia M., Caro R., 2000. Zinc as an essential micronutrient. NutritionalResearch, 20, 737-755.

[26] ATSDR 2005b. Toxicological profile for Zinc. Atlanta, Georgia, United States. US Department of Health and Human Services. Agency for Toxic Substances and Disease Registry.

[27] Gyorffy E.J., Chan H. 1992. Copper deficiency and mycrocyticanemia resulting from prolonged ingestion of over-the-counter zinc. American Journal of Gastroenterology, 87, 1054-1055.

[28] Barone A., Ebesh O., Harper R.G., Wapnir R.A. 1998. Placental copper transport in rats: effects of elevated dietary zinc on fetal copper, iron and metallothionien. Journal of Nutrition 128, 1037-1041.

[29] Elinder C.G. 1986. Zinc, New York, NY, Elsevier Science Publishers.

[30] Cotran R.S., Kumar V., Robbins S.L. 1989. Robbins pathologic basis of disease. Philadelphia, PA: W.B, Saunders Company.

[31] FAO, (1983). Compilation of legal limits for hazardous substances in fish and fishery products. FAO Fishery Circular, No. 464, pp:5-100.

[32] ATSDR 2004a. Toxicological Profile for Copper. Atlanta, Georgia, United States. US Department of Health and Human Services. Agency for Toxic Substances and Disease Registry.

[33] Verla Evelyn Ngozi, Verla Andrew Wirnkorand Enyoh Christian Ebere (2017)..Pollution assessment models of surface soils in Port Harcourt city, Rivers State, Nigeria.World News of Natural Sciences (WNOFNS) 12, 1-20.

[34] ATSDR 1999a. Toxicological Profile for Cadmium and Nickel. Atlanta, Georgia, United States. US Department of Health and Human Services. Agency for Toxic Substances and Disease Registry.

[35] Kumar E.R., Osman A., Wuertz S., Mekkawy I., Exner H., Kirschbaum F. (2006). Lead Induced Malformations in Embryos of the African Catfish ClariasGariepinus (Burchell, 1822). Environmental Toxicology, Vol. 22, No. 4, pp. 375-389.

[36] Kumar E.R., Ekeh C.A., Moslen M. (2008). Cadmium and lead level in some fish species from Azuabie creek in the Bonny Estuary, Nigeria. African J. Biotech., 7, 63-64.

[37] Kumar E.R., Bhadravathi R.K., (2005). Heavy Metal Transport in a sewage fed Lake of Karnataka, India. Proceedings of Taal 2007. The 12th World Lake Conference. 347-354.

[38] Olsson and Hogstrand, 1987 Determination osf some metal levels in muscles and tissues of nine fish species from Bysehir Lake, Turkey. Turkish Journal of fisheries and Aquatic sciences Vol. 12: (761-770).

[39] Canli, M., Atli G. 2003. The relationships between heavy metal ( $\mathrm{Cd}, \mathrm{Cr}, \mathrm{Cu}, \mathrm{Fe}, \mathrm{Pb}, \mathrm{Zn})$ levels and the size of six Mediterranean fish species. Environmental Pollution 121(1):129-36. doi: 10.1016/S02697491(02)00194-X.

[40] Bashir F.H., Othman M.S., Mazlan A.G., Rahim S.M., Simon K.D. 2013. Heavy metal concentration in fishes from the coastal waters of Kapar and Mersing, Malaysia. Turkish Journal of Fisheries and Aquatic Sciences, 13: 375-382.

[41] Kwon Y.T., Lee C.W. 2001. Ecological risk assessment of sediment in wastewater discharging area by means of metal speciation. Microchemical Journal, 70 (3): 255-264.

[42] FAO/WHO 1989. Evaluation of certain food additives and the contaminants mercury, lead and cadmium, WHO Technical Report, Series No. 505.

[43] UNEP, (1986): Assessment of the present state of pollution by cadmium, copper, zinc and lead in the Mediterranean Sea. Document UNEP/WG. 144/11 (Athen: UNEP).

[44] USEPA 2016, https://www.epa.gov/national-air-toxics-assessment/nata-glossary-terms,3:35

Citation: Verla Andrew Wirnkor, et.al, "Model Assessment of Potential Risk Associated with Common Fish Species from Oguta Lake, Nigeria”, International Journal of Advanced Research in Chemical Science, 7(9), pp. 09-18. DOI: https:// doi.org/10.20431/2349-0403.0709002

Copyright: () 2020 Authors, this is an open-access article distributed under the terms of the Creative Commons Attribution License, which permits unrestricted use, distribution, and reproduction in any medium, provided the original author and source are credited. 